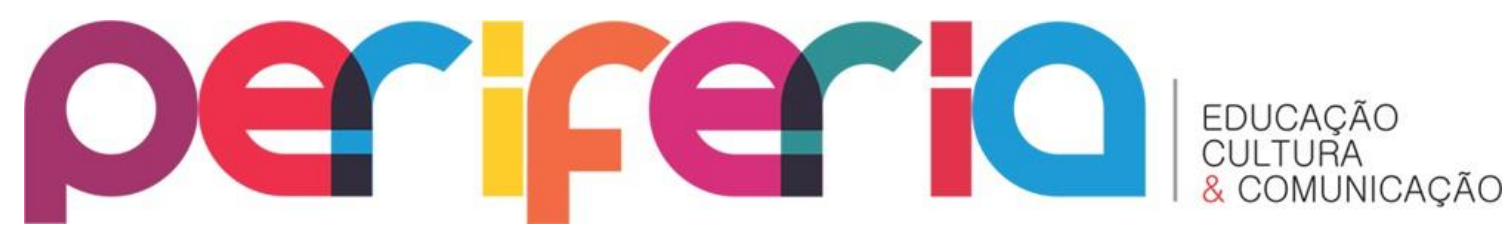

ISSN:1984-9540

DOI: $10.12957 /$ periferia.2019.36856

\title{
MEMES E A EDUCAÇÃO DE JOVENS E ADULTOS
}

\section{RESUMO}

Daniele Santana de Melo ${ }^{1}$ Universidade Federal do Sergipe

0 presente artigo aborda os memes no contexto educacional. Trata-se de um estudo de caso desenvolvido na disciplina de Educação de Jovens e Adultos (EJA), em uma faculdade da rede privada, localizada em Coronel João Sá - Bahia. Tem como objetivo geral apresentar os memes através de suas potencialidades de interpretações das informações dos alunos e ex-alunos da modalidade Educação de Jovens e Adultos, a partir de dados estabelecidos nas entrevistas realizadas pelos discentes do curso de pedagogia da disciplina Educação de Jovens e Adultos. Acrescido a isso, mostrar as concepções dos alunos e ex-alunos da EJA e, com base nas informações, reconfigurar a prática docente, apontando quais os tipos de memes que podem contribuir nas/para ações pedagógicas. Embora estejamos imbricados na sociedade marcada como a era da informação, das tecnologias móveis, com rápido e fácil acesso de informações, ou seja, mais independentes para buscar assuntos diversos e, entre eles, os de curiosidades, constatamos nesta pesquisa que existe a necessidade de reconfigurar materiais didáticos para a prática docente em especial.

Palavras-chave: Memes; Educação; Práticas Docentes; Cultura Digital; Educação de Jovens e Adultos.

\footnotetext{
${ }^{1}$ Mestrado em Educação. Professora e Coordenadora do Curso de Pedagogia FANEB. Professora Substituta UFS/Itabaiana. E-mail: danieleeli@hotmail.com
} 


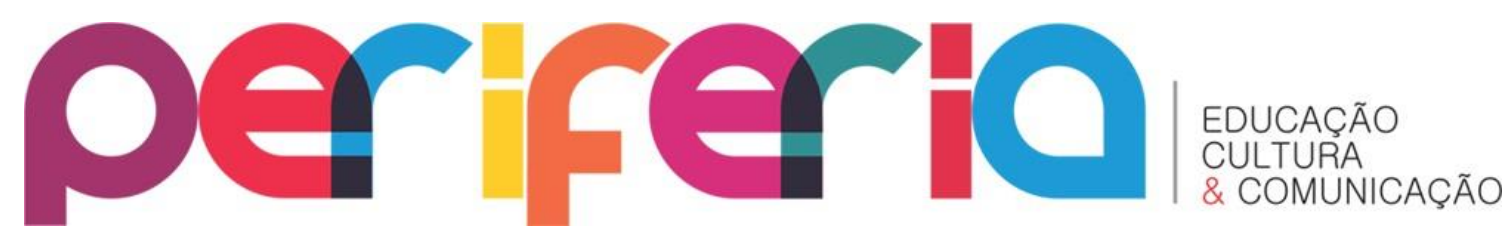

ISSN:1984-9540

DOI: $10.12957 /$ periferia.2019.36856

\section{MEMES AND YOUTH AND ADULT EDUCATION}

\section{ABSTRACT}

This article addresses the memes in the educational context. It is a case study developed in the discipline of Youth and Adult Education (EJA), in a private school college, located in Coronel João Sá - Bahia. It has as general objective to present the memes through its potentialities of interpretations of the information of students and alumni of the youth and adult education modality, based on data established in the interviews conducted by the students of the course of pedagogy of the discipline of Youth and Adult Education. In addition to this, to show the conceptions of the students and alumni of the EJA, and based on the information reconfiguring the teaching practice, pointing out the types of memes that can contribute in / to pedagogical actions. Although we are imbricated in the society marked as the information age, of the mobile technologies, with quick and easy access of information, that is, more independent to look for diverse subjects, and among them the curiosities, we find in this research that there is a need to reconfigure didactic material for the teaching practice in particular.

Keywords: Memes; Education; Teaching Practices; Digital Culture; Youth and Adult Education. 


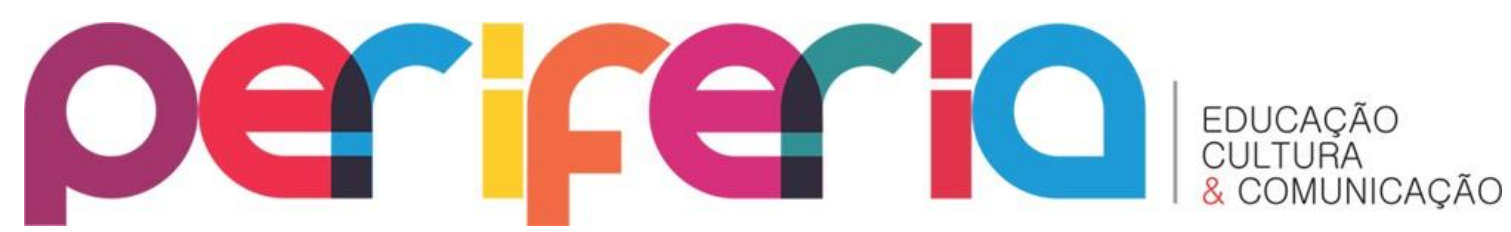

ISSN:1984-9540

DOI: $10.12957 /$ periferia.2019.36856

\section{MEMORES Y LA EDUCACIÓN DE JÓVENES Y ADULTOS}

\section{RESUMEN}

El presente artículo aborda los memes en el contexto educativo. Se trata de un estudio de caso desarrollado en la disciplina de Educación de Jóvenes y Adultos (EJA), en una facultad de la red privada, ubicada en Coronel João Sá - Bahía. El objetivo es presentar los memes a través de sus potencialidades de interpretaciones de las informaciones de los alumnos y ex alumnos de la modalidad Educación de Jóvenes y Adultos, a partir de datos establecidos en las entrevistas realizadas por los alumnos del curso de pedagogía de la disciplina Educación de Jóvenes y Adultos. A esto se añade la concepción de los alumnos y ex alumnos de la EJA, y con base en las informaciones reconfigurar la práctica docente, apuntando cuáles son los tipos de memes que pueden contribuir en la / a acciones pedagógicas. Aunque estamos imbricados en la sociedad marcada como la era de la información, de las tecnologías móviles, con rápido y fácil acceso de informaciones, o sea, más independientes para buscar asuntos diversos, y entre ellos los de curiosidades, constatamos en esta investigación que existe la necesidad de reconfigurar materias didácticas para la práctica docente en especial.

Palabras clave: Memes; la educación; Prácticas Docentes; Cultura Digital; Educación de Jóvenes y Adultos. 


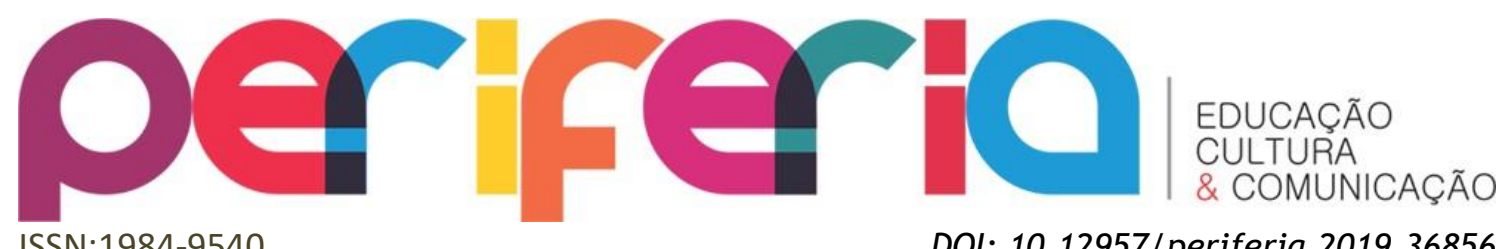

ISSN:1984-9540

DOI: $10.12957 /$ periferia.2019.36856

INTRODUÇÃO

Percebe-se que, no contexto atual, vem eclodindo com maior intensidade as abordagens sobre memes nas redes sociais em diversas esferas, tais como propagandas comerciais, eventos pontuais como a Copa do Mundo, entre outros. Por sua vez, com a presença dos memes amplamente fomentados na cultura digital, emerge também a sua marca na educação. Atrelado à sociedade digital, que evidencia nos aplicativos e nas redes sociais imagens, informações, publicações e campanhas por meio de postagens, a exemplo de vídeos, atribui-se o fomento por um espaço para discussões e conhecimentos a respeito do assunto.

No campo educacional, pensar, falar ou discutir sobre os memes na sala de aula corresponde a uma temática ainda desafiadora. Diríamos que são assuntos pertinentes que os profissionais da educação podem abordar em seu cotidiano escolar, uma vez que, na formação inicial e continuada, tenham tido a oportunidade de obter uma base teórica sobre o mesmo.

Além disso, a sociedade continua em constante mudanças e novos anseios dos indivíduos vão surgindo. Assim, os profissionais necessitam estar na formação continuada a fim de atualizarem seus conhecimentos. É nesta perspectiva que, atualmente, na sociedade digital, há a presença marcante das Tecnologias Digitais da Comunicação e Informação (TDIC), inseridas também no ambiente escolar.

Nota-se que as tecnologias móveis são instrumentos de fácil acesso e amplamente presentes no cotidiano das pessoas, visto que em curto espaço de tempo, através da internet, elas disponibilizam um campo vasto de informações, relevantes ou não para a aquisição de conhecimento.

Levando em conta a natureza interativa dos sites de pesquisa, onde há espaço para comentários e/ou opiniões, chats para debates, conversas públicas e privadas, e ainda a vulnerabilidade das redes sociais, pode-se dizer que, na mesma medida em que essas ferramentas representam um meio eficaz de comunicação de amplitude cada vez maior, que contribuem não só para a aquisição de conhecimentos, mas também na formação de opinião dos que as utilizam, novos 


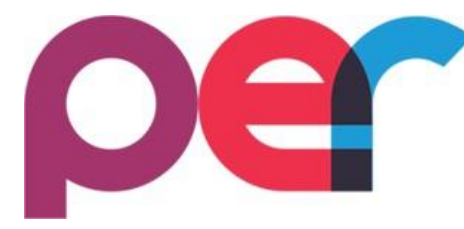

ISSN:1984-9540

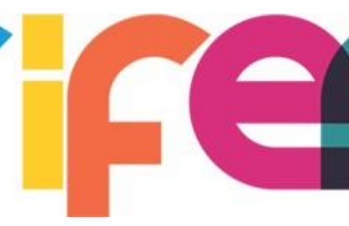

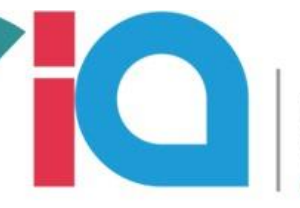

DOI: 10.12957/periferia.2019.36856

desafios surgem a todo o momento. Isto porque a velocidade com que as informações, ideias, opiniões, imagens, etc., circulam no mundo digital põe em dúvida a qualidade da mensagem. Percebe-se, principalmente, que há muitas informações que vão de encontro à integridade do indivíduo.

Desse modo, o âmbito educacional, que proporciona também esse encontro de pessoas mediante seu aspecto de comunidade educativa, corrobora com a busca por saberes e conhecimentos, tanto pedagógicos quanto na conjuntura da vivencia social. Assim, este artigo traz a pergunta: De que forma os memes podem contribuir com as práticas pedagógicas na Educação de Jovens e Adultos?

Desta feita, elencou-se também como finalidade apresentar os memes como potencialidades para interpretações das informações dos alunos e ex-alunos da modalidade Educação de Jovens e Adultos (EJA), a partir de dados estabelecidos em entrevistas realizadas pelos discentes do curso de pedagogia, da disciplina Educação de Jovens e Adultos. Estas entrevistas ocorreram em cidades vizinhas de Coronel João Sá. Acrescido a isso, mostrar as concepções dos alunos e ex-alunos da EJA acerca da temática e, com base nas informações obtidas, reconfigurar a prática docente e apontar quais os tipos de memes que podem contribuir nas/para ações pedagógicas.

Este estudo é caracterizado como um estudo de caso, efetivado por meio da realização de uma entrevista dos alunos da disciplina Educação de Jovens e Adultos (EJA), junto aos alunos, ex-alunos e uma educadora, ambos da EJA. Com base em Richardson (1999, p. 88), "a coleta de dados, entrevistas, observações e discussões em grupo podem enriquecer as informações obtidas, particularmente, pela profundidade e pelo detalhamento das técnicas qualitativas".

\section{Memes reconquistando os espaços no viés da EJA}

Os memes, sempre repercutindo no cotidiano das sociedades contemporâneas, estão intensificados principalmente nas redes sociais. Na linha do tempo, é possível já observar sinalizados estudos sobre os memes no século XX, 


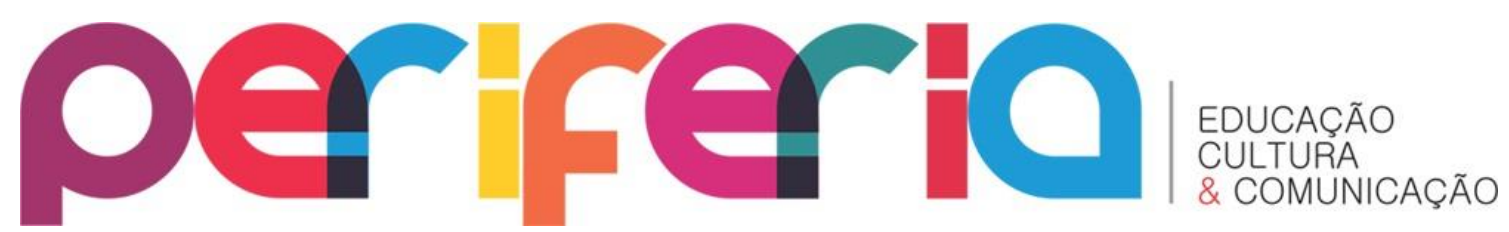

ISSN:1984-9540

DOI: $10.12957 /$ periferia.2019.36856

através do trabalho e do estudo do biólogo Richard Dawkins com o livro intitulado "O Gene egoísta", pois o mesmo informa que:

Um 'meme de ideia' pode ser definido como uma entidade capaz de ser transmitida de um cérebro para outro. 0 meme da teoria de Darwin, portanto, é o fundamento essencial da ideia de que é compartilhado por todos os cérebros que a compreendem (DAWKINS, 2001, p. 217-218).

Dessa forma, a ideia é encaminhada por uma impressão para outros seres pensantes, como a citação enfatiza 'de um cérebro para outro'. Essa ideia ganha força e repercussão social. Ainda de acordo com Dawkins, é possível apontar três conceitos para a vida de um meme, sendo descritos pelo autor como: longevidade, fecundidade e fidelidade.

Constatamos que os memes sempre estiveram presentes nos contextos sociais, podendo ser encontrados em diversos seguimentos, a exemplo dos provérbios e aforismos, tais como: "Em casa de ferreiro, espeto de pau"; "Nada como um dia após o outro"; "Aquilo que não mata, torna-nos mais fortes"; "Rir é o melhor remédio"; dentre outros. Assim, são ditos populares que repercutem de gerações em gerações e que são aplicados em nosso cotidiano, ou seja, conhecimentos não necessariamente científicos sobre a vida. Percebe-se que não há dificuldade em decorar, por serem engraçados e, consequentemente, mais fáceis de repassar. Sobretudo, muitos desses memes são frases que permitem autorreflexão sobre a vida.

De acordo com Maciel e Takaki, memes "significa tudo que pode ser copiado de uma mente para outra" cintando Lankshear e Knobel (2007, p. 211), é o que "diretamente molda e propaga ações-chave de um grupo social". Assim, ocorre a proliferação de transmissão da informação que vai desencadeando novos assuntos, temas e críticas que surgem no dia a dia.

Os memes estão presentes em várias esferas sociais, como TV, rádios, músicas, estilos e, mais especificamente, no contexto online, produzidos com um objetivo discursivo de propagação de ideias, 


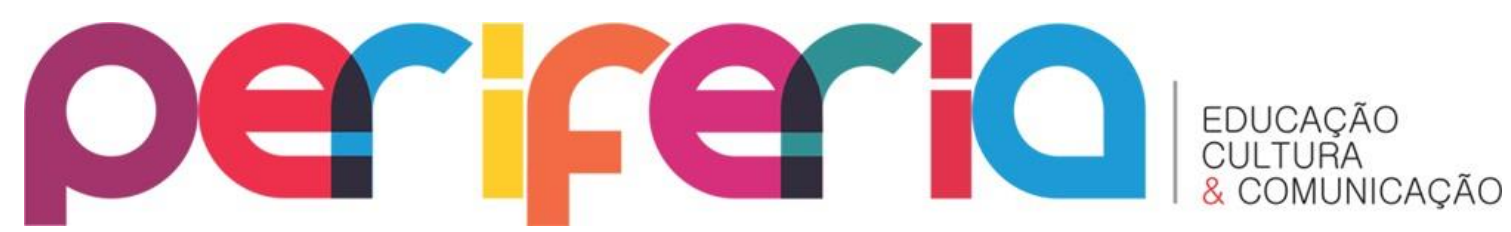

ISSN:1984-9540

DOI: $10.12957 /$ periferia.2019.36856

merece atenção na e pela instituição de ensino (MACIEL; TAKAKI, 2015, p. 79).

Observa-se que esta frase de ordem: 'merece atenção na e pela instituição de ensino', deve pairar nas atuais práticas de ensino, bem como em todo o âmbito escolar. Trata-se de uma assertiva que necessita ações para gerenciar a organização de materiais plausíveis na conjuntura educacional.

[...] os memes representam modelos culturais de pensamentos, ideias, pressupostos, valores, esquemas interpretativos de fenômenos sociais simbólicos e comportamentais que são produzidos por participantes [...] (MACIEL; TAKAKI, 2015, p. 57)

$\mathrm{Na}$ conjuntura das redes sociais os memes estão bem reconfigurados, pois, normalmente estão reapresentando o esteio contemporâneo nas diversas esferas sociais, econômicas, políticas, entre outros.

Diante de tal contexto é preciso considerar que não é diferente na educação, haja vista a existência de diversos exemplos plausíveis de educadores que já utilizam os memes como material pedagógico. Contudo, ainda é um material desconhecido por alguns, chegando a ser pensado como algo novo e recente. Cabe salientar que, conforme referências já mencionadas, existem bases que comprovam sua existência em séculos anteriores à internet. Mas vale mencionar que os memes são modelos culturais que podem e devem ser produzidos de forma colaborativa.

Em âmbito ilustrativo, o quadro abaixo destaca algumas das ações pedagógicas que podem contribuir com o processo educacional no espaço escolar. Trata-se de exemplos do livro intitulado: Olhares sobre tecnologias digitais: linguagens, ensino, formação e prática docente (JESUS; MACIEL, 2015). Com base em Recuero (2006), os autores mencionam sobre a fidelidade da cópia, tratadas por Dawkins.

Quadro 1 - Compreendendo os Memes

\begin{tabular}{|c|c|c|c|}
\hline & CONCEITO & OBJETIVO & $\begin{array}{c}\text { PLANO DE AÇÕES } \\
\text { PEDAGÓGICAS }\end{array}$ \\
\hline
\end{tabular}




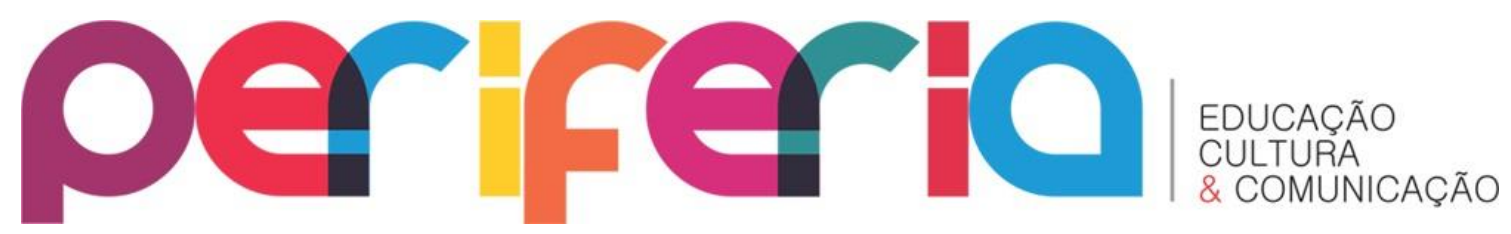

ISSN:1984-9540

DOI: 10.12957/periferia.2019.36856

\begin{tabular}{|c|c|c|c|}
\hline $\begin{array}{l}\text { 1- } \\
\text { Replicadores }\end{array}$ & $\begin{array}{lr}\text { São copiados } & \text { de } \\
\text { sites e por } & \text { isso } \\
\text { retratam } & \text { alta } \\
\text { fidelidade } & \text { em } \\
\text { relação à } & \text { versão } \\
\text { 'original'. } & \end{array}$ & $\begin{array}{lr}\text { Informar } & \text { e } \\
\text { compartilhar } & \\
\text { informações } & \text { sem } \\
\text { acréscimos } & \text { de } \\
\text { opiniões. } & \end{array}$ & $\begin{array}{lr}\text { Promover o encontro } \\
\text { simultâneo } \\
\text { imagens, de } \\
\text { animações sons, } \\
\text { linguagem verbal. }\end{array}$ \\
\hline $\begin{array}{l}\text { 2- } \\
\text { Metamórficos }\end{array}$ & $\begin{array}{l}\text { São mutáveis e } \\
\text { recombinados e, } \\
\text { diferentemente dos } \\
\text { anteriores, podem } \\
\text { ser empregados em } \\
\text { contexto de debate. }\end{array}$ & $\begin{array}{lr}\begin{array}{l}\text { Permitir que } \\
\text { informação }\end{array} & \text { a } \\
\text { debatida, } & \\
\text { transformada } & \text { e } \\
\text { recombinada. } & \end{array}$ & $\begin{array}{l}\text { Incentivar } \\
\text { posicionar-se } \\
\text { criticamente com } \\
\text { relação ao material } \\
\text { produzido. }\end{array}$ \\
\hline 3- Mimétricos & $\begin{array}{l}\text { São o que mantêm a } \\
\text { "essência”, embora } \\
\text { sofram } \\
\text { recombinações, ou } \\
\text { mutações, e podem } \\
\text { ser referenciáveis } \\
\text { como imitações. }\end{array}$ & $\begin{array}{lr}\text { Relacionar } & \text { os } \\
\text { mimétricos } & \text { ao } \\
\text { aspecto de escrita } \\
\text { criativa, } & \text { de } \\
\text { representação } & \text { de } \\
\text { narrativas, de críticas } \\
\text { sociais e mensagens } \\
\text { agradáveis. }\end{array}$ & $\begin{array}{l}\text { Estimular criação e } \\
\text { recriação. }\end{array}$ \\
\hline
\end{tabular}

Fonte: Elaborado pela autora com base em Maciel e Takaki (2015, p. 62 a 64)

As informações no quadro acima podem nortear segmentos pedagógicos a serem trabalhados no âmbito escolar, bem como no viés colaborativo, atrelado, consequentemente, ao contexto sociodigital. Salienta-se, então, que, por mais que os memes não tenham sido pensados como material didático escolar, é possível e necessário repensar sua utilização no campo educacional.

Desse modo, percebe-se que as contribuições já existentes no universo científico, nas redes sociais, como também na própria escola, podem ser utilizadas junto com o corpo docente e discente, tendo como finalidade reconstruir materiais que retratem o seu cotidiano.

Os conhecimentos assim adquiridos, mesmo não sendo necessariamente os escolares, integram-se à bagagem cultural dos alunos, embora não costumem ser valorizados pelos professores ou pela escola; ao contrário, há até certo estigma sobre o "excesso" de tempo que os jovens passam na internet (GOMES, 2016, p. 82). 


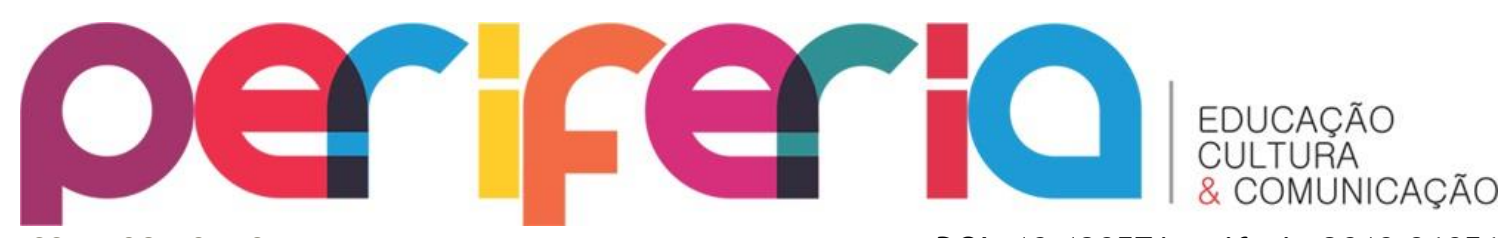

ISSN:1984-9540

DOI: $10.12957 /$ periferia.2019.36856

Conforme Gomes anuncia, os alunos estão cada vez mais valorizando o tempo nas redes sociais, adquirindo e trazendo consigo a bagagem cultural vivenciada no contexto digital, ou seja, estão munidos de informações extraescolares. Assim, a escola pode atuar de modo a transformar essas informações em conhecimentos, aguçando os professores para a quebra de preconceito quanto ao uso da internet.

As redes sociais de relacionamento têm permitido e potencializado novas formas de ser e de estar no mundo, de ensinar e de aprender. Aprender-se em todos os lugares e, nesse sentido, podemos mesmo dizer que há uma escola fora da escola (GOMES, 2016, p. 83).

No caso dos memes, que ainda revolucionam o nosso cotidiano e são responsáveis por ampla repercussão de ideias nas redes digitais, estão presentes no cotidiano dos alunos através dos dispositivos móveis, representando uma "entidade" emissora de ideias e opiniões sobre variados assuntos.

De fato os alunos têm aprendido e "ensinado" sobre o uso dos memes em diversos espaços, tanto na escola quanto fora dela. Tem-se, então, que o contexto socialdigital permite novas criações de materiais digitais, a exemplo de jogos de perguntas e respostas, vídeos, textos, músicas, imagens, histórias em quadrinho, podendo contemplar diversas temáticas. Trata-se de Recursos que podem efetivamente contribuir com a qualidade educacional. Com os memes eles podem ser Replicadores, Metamórficos e Mimétricos, conforme descrito no quadro 1. Ademais, permite um conjunto de possibilidades de criação, animação, bem como novas reflexões a respeito da temática abordada.

A escola, nos dias atuais, é desafiada a compreender o mundo complexo e caótico das relações humanas no trabalho e na educação e a se reinventar, para continuar mantendo sua importância, que vai além da acreditação e da distribuição de diplomas (GOMES, 2016, p. 89). 


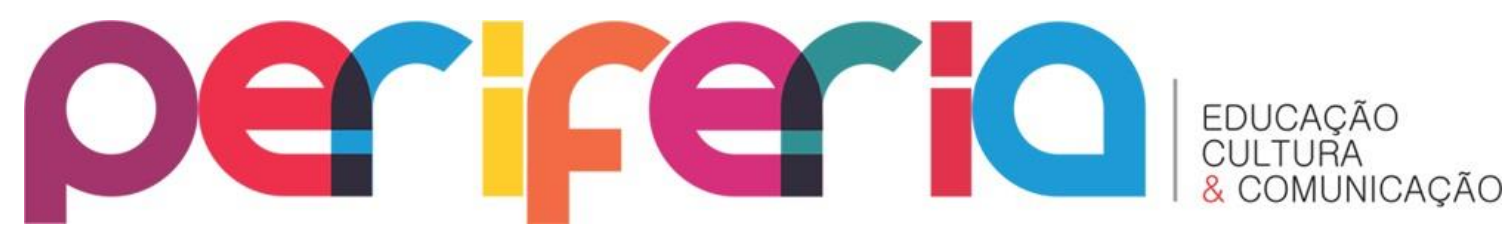

ISSN:1984-9540

DOI: $10.12957 /$ periferia.2019.36856

Esse desafio escolar está na trilha da velocidade da informação e da comunicação, sinalizada através da presença implícita e explicita das Tecnologias da Informação e Comunicação TIC, termo atualizado para Tecnologia Digital da Informação e Comunicação TDIC, cuja mudança corresponde ao fato de que a sociedade encontrar-se na era digital, onde tudo e todos estão imbuídos nessa dinâmica tecnológica.

Entretanto, Vale ressaltar que existem memes nocivos, marcados com ideias de preconceito, racismo, discriminação entre outros, suscitando a necessidade de combater tais ideias maléficas entre os consumidores destes conteúdos. Este é um aspecto desafiador para todos os agentes da escola: tratar de ações educacionais na busca do enfrentamento destes conteúdos.

Desta feita, esta abordagem teórica parte do princípio de que a escola deve repensar suas ações de acordo com o cenário atual das sociedades, relacionado os conteúdos e as abordagens ao contexto local em que está inserida. Razão pela qual a urgência de focar a prática docente com as culturas digitais.

\section{As Culturas digitais na prática docente}

Nota-se que os memes são elementos das culturas digitais que trazem possibilidades para as práticas docentes, e que, no espaço virtual, já existem diversos materiais de apoio educativo que contribuem para ampliar novos conhecimentos, além de agregar informações, semelhantes ou não, permitindo serem utilizados como suporte ao processo educativo.

Assim, corrobora-se com a afirmação de Maciel e Takaki, "o ciberespaço e sua relação com os memes podem contribuir para uma ponte entre escolas e sociedade" (2015, p. 80). Observa-se, então, que o espaço virtual, juntamente com os memes, marca do sociodigital, podem contribuir para a inclusão dos indivíduos como cidadãos autônomos no processo de aprendizado. Trata-se de uma perspectiva em que estes são protagonista, isto é, são sujeitos ativos que interagem com autonomia na sociedade. 


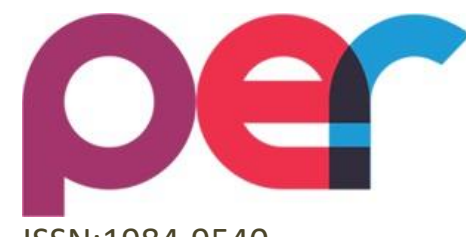

ISSN:1984-9540

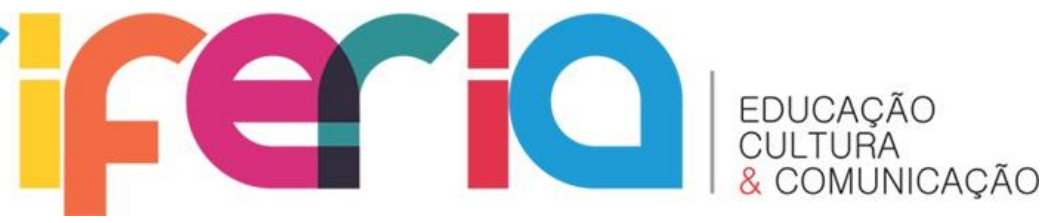

DOI: $10.12957 /$ periferia.2019.36856

Como sinaliza Jenkins, "prontos ou não, já estamos vivendo numa cultura da convergência" (2009, p. 43). Daí a necessidade de nós, professores, estarmos sempre proativos na busca por atualização com vistas à tendência sociodigital, apontada sobre a realidade das vivencias atuais, sendo capazes de relacioná-las com as questões educacionais.

Nesse contexto, Snyder defende que "os professores precisam reconhecer a importância da cultura popular, ou perderão alguns dos elementos mais importantes no entendimento do aluno e suas vidas" (2002, p. 180). Essa citação é crucial em nosso processo da prática docente, uma vez que a cultura popular vai sendo revelada nas dinâmicas das aulas, podendo ser manifestada dentro ou fora do espaço escolar.

Tal reflexão reforça a importância de não camuflar esse saber popular, devendo, de modo contrário, ser utilizado para potencializar e somar o saber científico. Além disso, é preciso repensar a prática docente fundamentada na tríade da ação-reflexão-ação, pois ela nos remete não só a autoavaliação, como também a agregar novas possibilidades de ensino em prol da aprendizagem.

O que é relevante para ser ensinado ou aprendido hoje pode não ser amanhã [...] é muito mais importante produzir aprendizes capazes de buscar o saber em constante mudança, do que aprender um conteúdo fixo e, supostamente, dominá-lo para o resto de sua vida. Precisamos enfatizar como aprender, mais do que o que aprender (MENEZES DE SOUZA, 2010).

Diante de tantas mudanças, sobressaem os desafios sobre o que ensinar e o que aprender, dentro das possibilidades do que estamos vivenciando. Assim, o foco é estar discutindo, de fato, como aprender. Porém, relevar no aprendiz o discernimento das situações.

É imprescindível compreender que estamos em uma sociedade de constantes mudanças e, em consequência, as pessoas também seguem esse esteio de transformações físicas e intelectuais. Assim, há necessidade de "ser crítico em relação a eles, no entanto, não se reduz a enxergar suas ideologias ou as intenções dos seus criadores, mas requer sempre uma abordagem contextualizada dos seus efeitos e implicações" (TAKAKI et al., s/a, p. 227-228). 


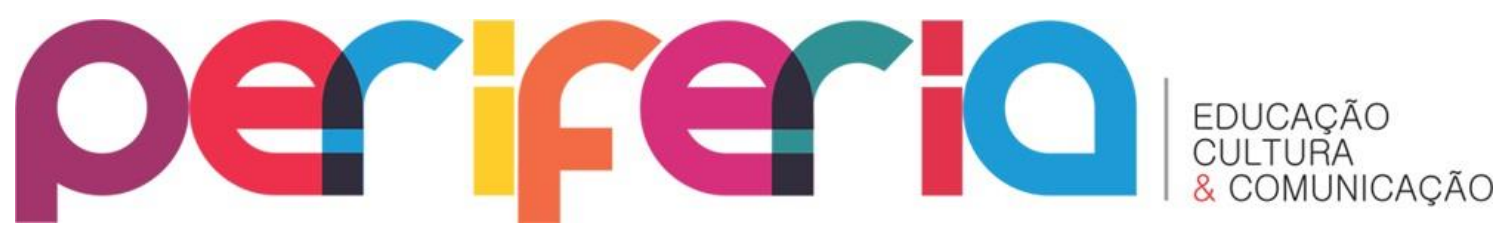

ISSN:1984-9540

DOI: $10.12957 /$ periferia.2019.36856

O perfil docente necessita aguçar nos alunos a utilização de uma lente crítica, ampliada em todo material encontrado no ciberespaço, ou até mesmo nos que serão postados, para não ficarem na postura ingênua. Dessa forma:

Quando a aprendizagem se encontra em céu aberto, qualquer aprendiz pode trazer, para o mestre, informações que este não detém. Conclusão: novas modalidades de diálogo estão emergindo, para as quais o professor deve estar preparado na medida em que tiver a segurança serena em relação ao fato de que ficou no passado a era na qual costumava ser o detentor altissonante da transmissão e da transferência de conhecimento (SANTAELLA, 2013, p. 307).

É nessa expectativa que os professores anseiam por mudanças significativas na postura de seus alunos, de modo que sejam protagonistas também no cenário escolar, trazendo materiais pertinentes para fomentar discussões, diálogos e análises críticas na trilha do conhecimento.

Para isso, fomenta-se a necessidade ao contexto da formação continuada em serviço. Braga (2013) nos chama a atenção sobre a cocriação de materiais a serem utilizados na prática de ensino.

A criação do "próprio material" pelo professor sempre foi uma alternativa defendida nos curso de formação para professores em serviço, que, em geral, tende a não refletir com a devida profundidade a natureza da tarefa proposta e as dificuldades diversas, inclusive financeiras, envolvidas no acesso a fontes de informação diversas, necessárias para a criação de novas atividades em sala de aula. Muitas vezes esses cursos de formação também não oferecem exemplos ilustrativos de atividades pedagógicas que podem servir de base de inspiração para adaptações ou criações de propostas mais locais (BRAGA, 2013, p.47).

Contudo, com base na autora supramencionada, são suscitadas algumas advertências plausíveis referentes à formação continuada em serviço, retratadas na necessidade de ilustrar as atividades na prática de ensino e na promoção de inspiração para serem sugeridas no contexto local. 


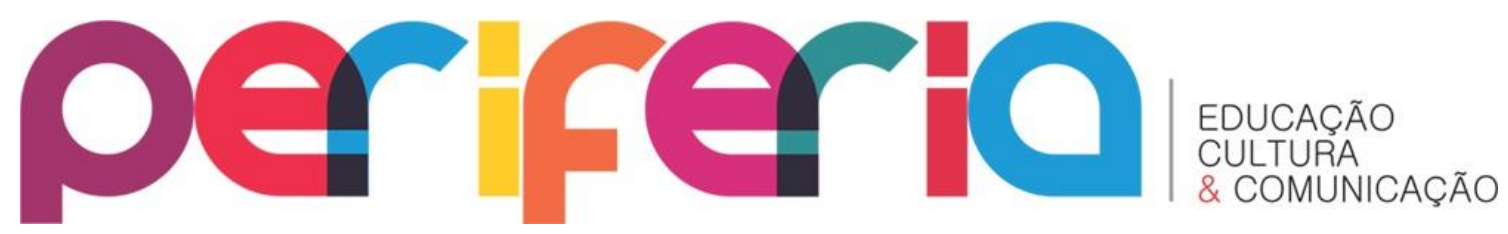

ISSN:1984-9540

DOI: $10.12957 /$ periferia.2019.36856

É nesse viés que os dados coletados para serem inseridos nesse artigo buscaram representar, através dos memes, a base das respostas dos dados obtidos nas entrevistas realizadas pelos alunos da disciplina da EJA.

\section{Resultados e discussões}

As entrevistas foram aplicadas no período de 05/06/2018 a 23/06/2018 nos turnos mesclados, de acordo com a disponibilidade dos entrevistados. Para os dados utilizados, tivemos a participação de 19 (dezenove) entrevistados, sendo 04 (quatro) alunos da EJA, 14 (quatorze) ex-alunos da EJA e 01 (um) Professora da modalidade EJA. Nesta amostra foram 12 (doze) do sexo feminino e 07 (sete) do sexo masculino. As profissões dos respondentes foram: 07 lavradoras, 01 vaqueiro, 01 costureira, 01 aposentado, 03 agricultores, 01 gerente de fazenda, 01 repositor e conferente de mercadorias de supermercado. 0 roteiro da entrevista foi o seguinte: 1 - Por que você decidiu estudar na EJA?; 2- Você já tinha estudado na EJA antes?; 3- Qual o motivo que o levou a voltar a estudar?; 4- 0 que o motiva a vir à aula?; 5- Quais as maiores dificuldades que tem enfrentado em sala de aula?; 6- Você recebe algum estímulo por parte dos profissionais da escola? Como?; 7- Você acha que os professores estão habilitados a trabalhar na EJA?; 8- O material que você usa corresponde a sua realidade? 9- Além do livro didático quais outros recursos os professores utilizam nas aulas?

Dentro das perguntas acima explicitadas, optou-se por destacar neste artigo alguns dados dos entrevistados, tendo sido escolhidas a primeira e a terceira pergunta, pois, a partir delas, é possível nos remeter a apresentação das concepções desses alunos e ex-alunos da EJA. O Quadro2 revela as respostas com base na pergunta 1.

Quadro 2 - pergunta 1- Por que você decidiu estudar na EJA? MEMES 


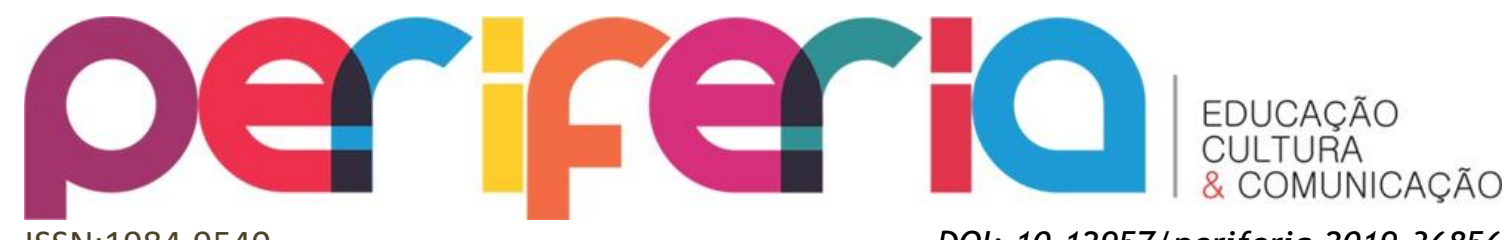

ISSN:1984-9540

DOI: $10.12957 /$ periferia.2019.36856

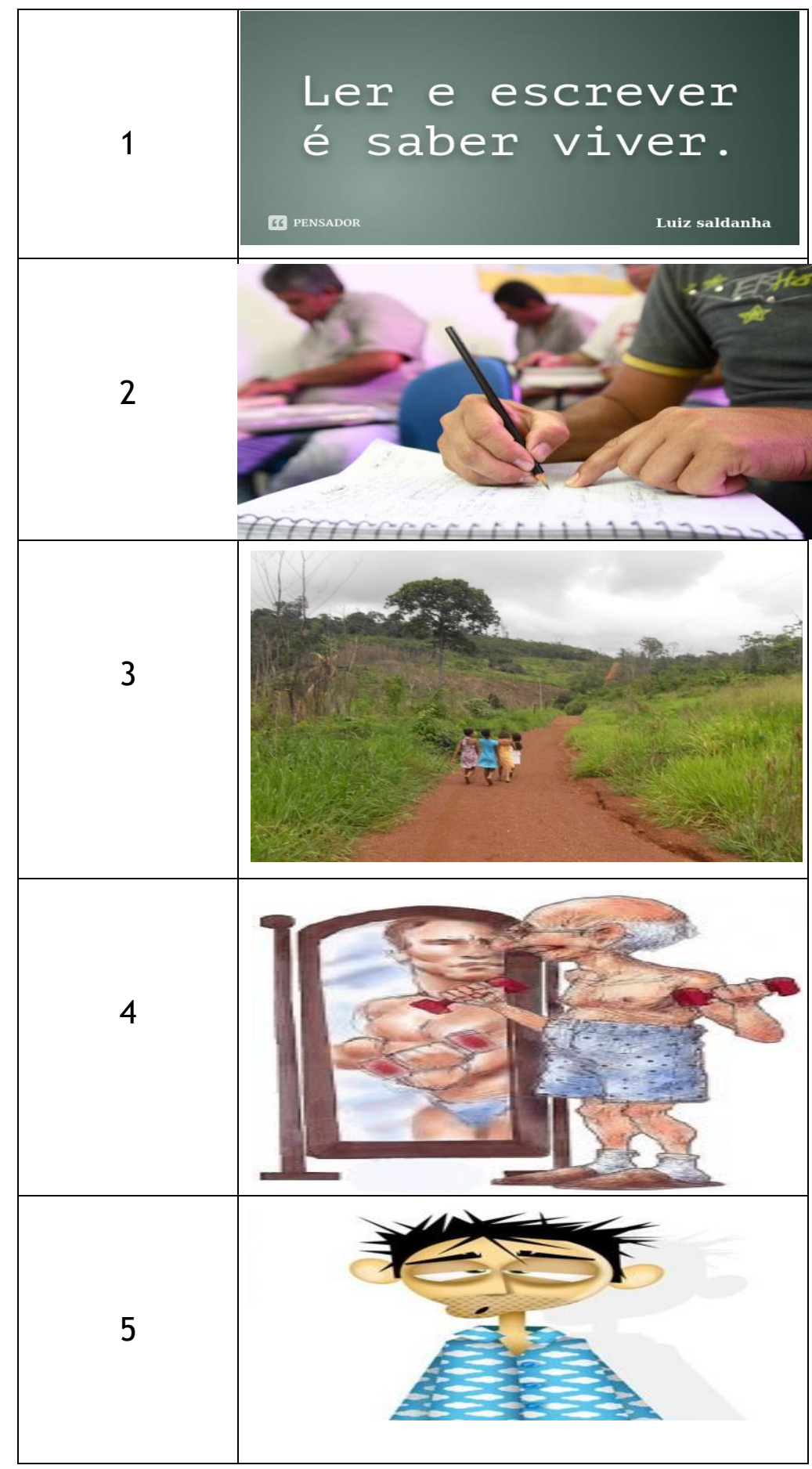

Fonte: Dados da entrevista (2018)

Estes memes (replicadores) representam algumas respostas dos alunos e exalunos da EJA entrevistados acerca do questionamento: Por que você decidiu estudar na EJA? 


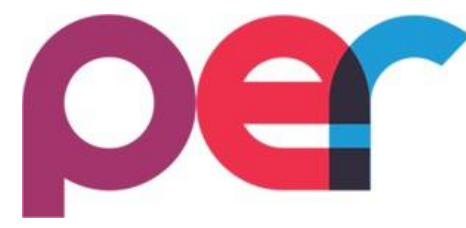

ISSN:1984-9540

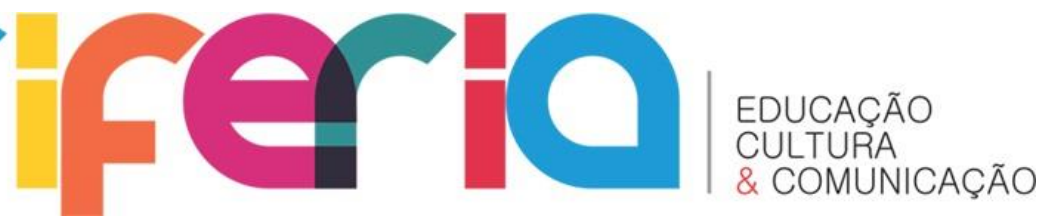

DOI: $10.12957 /$ periferia.2019.36856

A primeira imagem do Quadro 2 traz uma frase: "Ler e escrever é saber viver", na veracidade da resposta foi só "ler e escrever", mas nos remete à reflexão que, de fato, o ato de ler e escrever leva o indivíduo a saber viver de forma íntegra, com conhecimento de direitos e deveres. Por mais que estes ex-alunos tenham pensando somente na parte técnica do ato de escrever e ler, sabemos que eles precisam buscar conhecimentos emancipatórios. Isso também nos remete ao letramento crítico que "consiste em não apenas ler, mas ler se lendo, ou seja, ficar consciente o tempo inteiro de como eu estou lendo, como eu estou construindo o significado[...]" (MENEZES DE SOUZA, 2011, p. 296).

Já a segunda imagem representa o desejo de aprender a "escrever o nome". Trata-se de um aspecto que aborda a questão da identidade, autonomia e direito à cidadania.

A terceira imagem traduz que "escola muito distante de casa". Ela retrata uma das realidades brasileiras, pois muitos cidadãos da zona rural estão limitados pela falta de escolas próximas de suas residências, sendo que outro entrave, muitas vezes, está relacionado à falta de construção e/ou manutenção de estradas e rodovias, o que dificulta o acesso de transportes, ou ainda a ausência da fiscalização dos transportes escolares nestas regiões. São muitos os obstáculos que impedem o acesso dos moradores da realidade rural à escola.

A quarta imagem representa "idade avançada", e instiga o resgate da força ao retornar a estudar como sendo propulsora para o vigor de um jovem.

A quinta imagem quer dizer o "cansaço do dia a dia", pois a maioria dos entrevistados são trabalhadores rurais, que acordam cedo para cuidar da terra e dos animais, e já chegam em suas casas ao anoitecer. Porém, mesmo assim, com muita dificuldade, retornam aos estudos pela modalidade EJA.

Através desses depoimentos, foi possível conhecer um pouco da realidade dos ex-alunos da EJA, sendo que esta modalidade tem como objetivo oportunizar escolarização às pessoas que não conseguiram concluir na idade certa. Apesar da disponibilização da EJA, ainda são expressivos e recorrentes os impedimentos para 


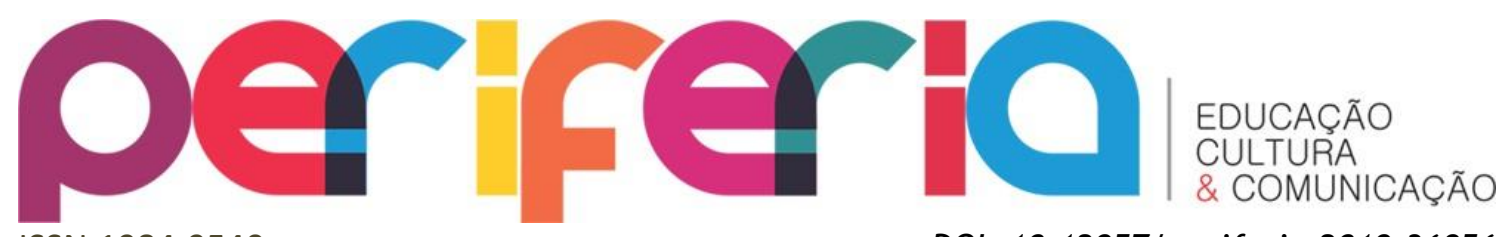

ISSN:1984-9540

DOI: $10.12957 /$ periferia.2019.36856

que estes estudantes possam avançar no direito de cidadania e acesso de qualidade ao ensino e aprendizagem.

O Quadro3 abaixo manifesta as respostas com base na pergunta: 3- Qual o motivo que o levou a voltar a estudar?

Quadro 3 - Pergunta 3- Qual o motivo que o levou a voltar a estudar?

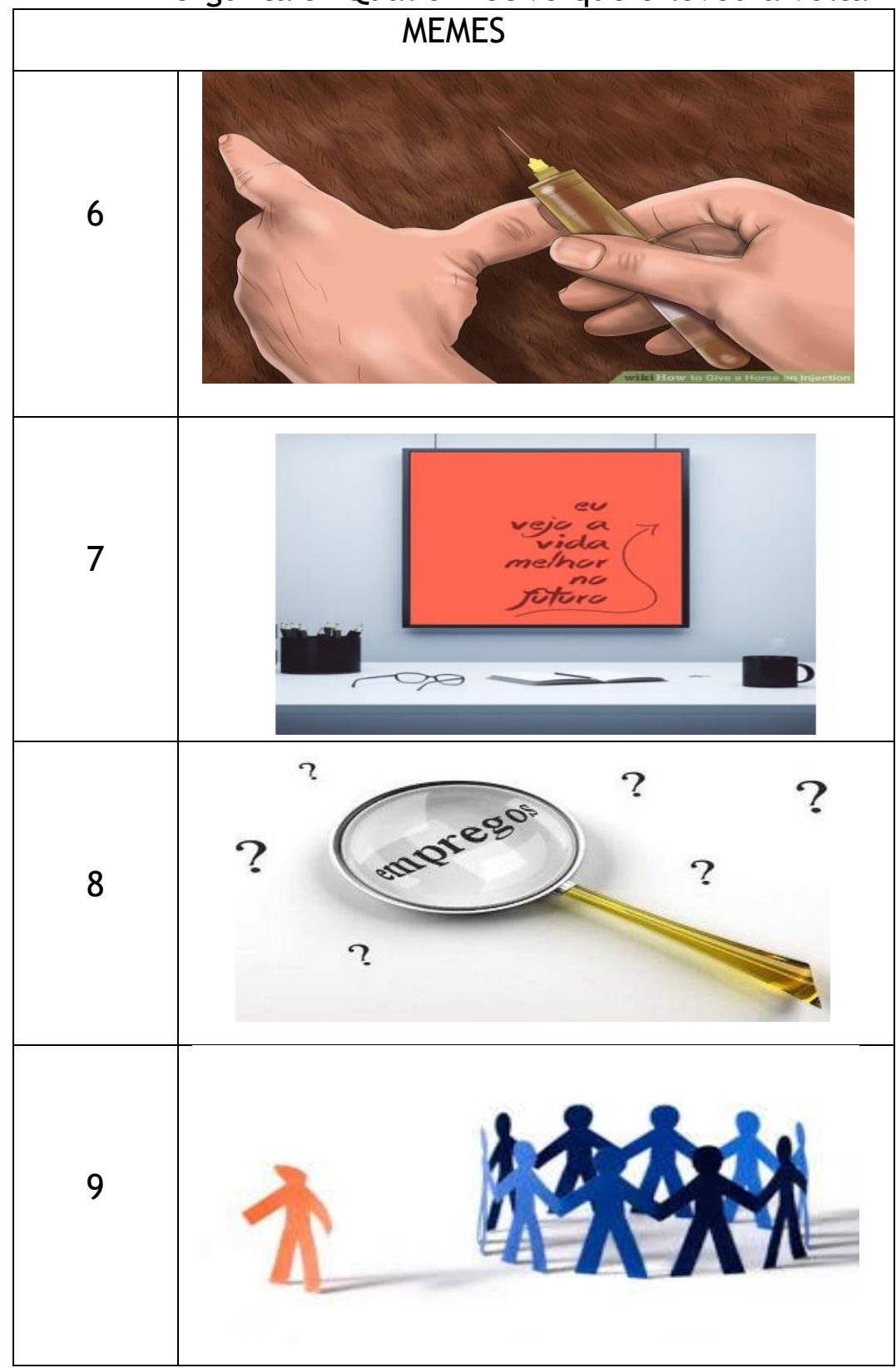




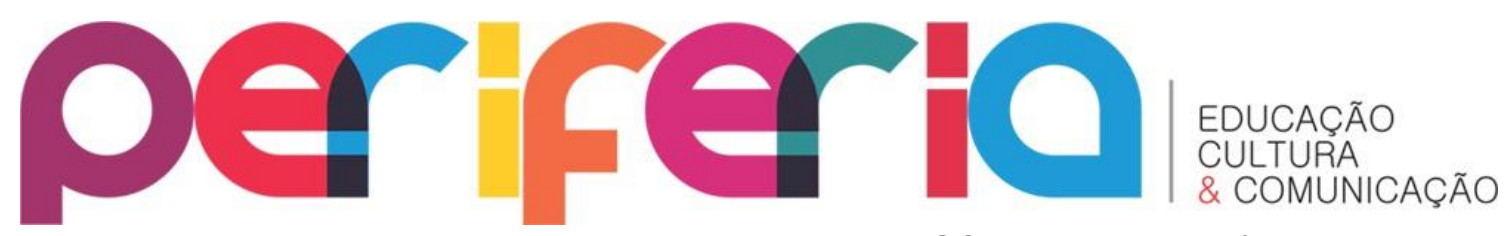

ISSN:1984-9540

DOI: $10.12957 /$ periferia.2019.36856

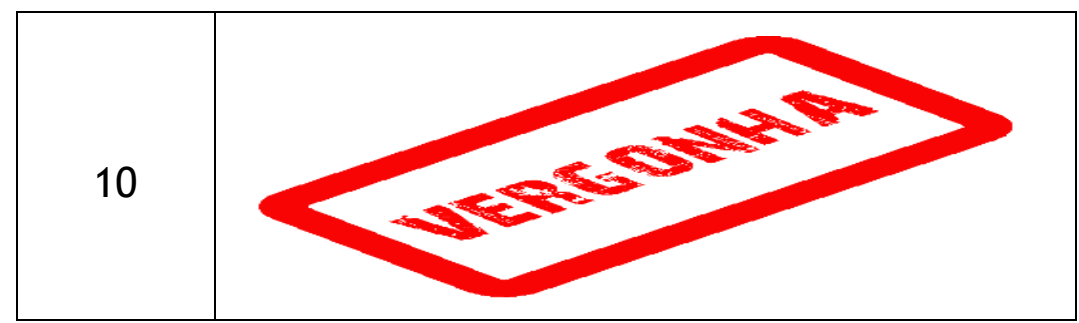

Fonte: Dados da entrevista (2018).

Os memes (replicadores) que estão inseridos no Quadro 3 abordam, com embasamento dos dados dos alunos e ex-alunos da EJA, as respostas referentes à pergunta: Qual o motivo que o levou a voltar a estudar?

0 meme 6 representa a resposta: "Para ler a bula das injeções dos remédios que davam nos animais", ou seja, retrata o desejo de compreender as informações da bula, representando uma questão da autonomia.

O meme 7 informa a frase "eu vejo a vida melhor no futuro", e concebe a veracidade da resposta "Para ser alguém melhor no futuro". Assim, a motivação de voltar a estudar está na esperança de mudança pessoal quanto à melhoria diante do tempo verbal 'futuro'.

Para o meme 8 a resposta foi: "Não estava encontrando emprego", ou seja, foi o mercado de trabalho que instigou o retorno a estudar, por não estar atendendo às exigências do mercado de trabalho que solicita outro nível escolar.

O meme 9 traduz " 10 anos sem estudar, excluídos e oprimidos, é o indivíduo que não tem estudo". A exclusão, em diversas esferas sociais, é marcada pela falta de escolaridade. Percebe-se que a motivação é retornar para a escola pensando em posteriormente ser incluído no contexto social.

O meme 10 apresenta a palavra "Vergonha", porém, manifesta a declaração de uma aluna "casei nova, tinha vergonha de voltar a estudar". Transcorre ao contexto de gênero, especificamente ao viés do preconceito e da discriminação, seja ela pessoal ou social.

Estas declarações nos permitiram reconhecer concepções peculiares desses alunos e ex-alunos da EJA. Motivações pertinentes que nos fazem reafirmar, diante 


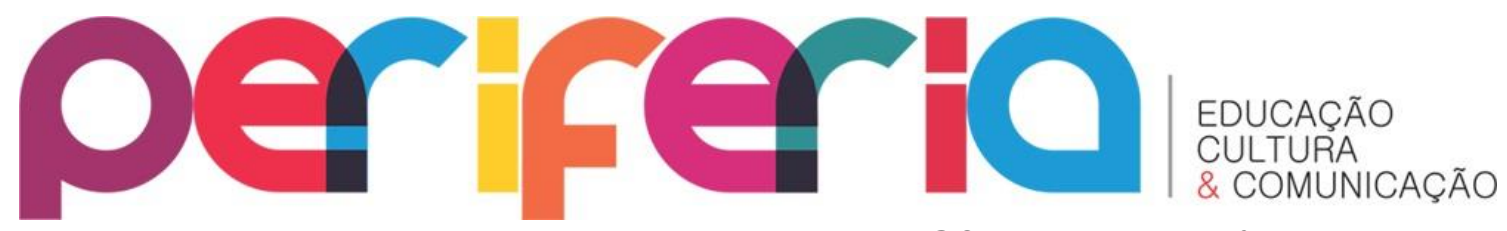

ISSN:1984-9540

DOI: $10.12957 /$ periferia.2019.36856

da nossa postura docente, ações e condutas para que possamos garantir a concretização dos sonhos almejados.

Na sequência, o Quatro 4 representa o depoimento da única educadora entrevistada da EJA. Em sua fala, ela evidenciou que muitos estudantes, que estavam na lista de alunos matriculados, já havia falecido. Ficamos estarrecidos com este depoimento e por isso a utilização do meme Metamórfico, pois representou o posicionamento crítico com tal informação.

O meme 11 sinaliza uma interpretação crítica à luz do depoimento já mencionado, pois delega a informação maquiada de uma política pública da Educação de Jovens e Adultos, de um determinado município da Bahia (não fomos autorizados a mencionar). 0 fato é que foram utilizados os nomes das pessoas já falecidas, como forma de justificar o quantitativo de estudantes matriculados, para que a verba destinada a EJA fosse enviada. É possível compreender que tal conduta comprova a ausência da ética, comprometimento e corresponsabilidade educacional, bem como a falta de fiscalização precisa acerca da demanda socioeducacional.

Quadro 4 - Você procurava estimular seus alunos de alguma forma? Como?

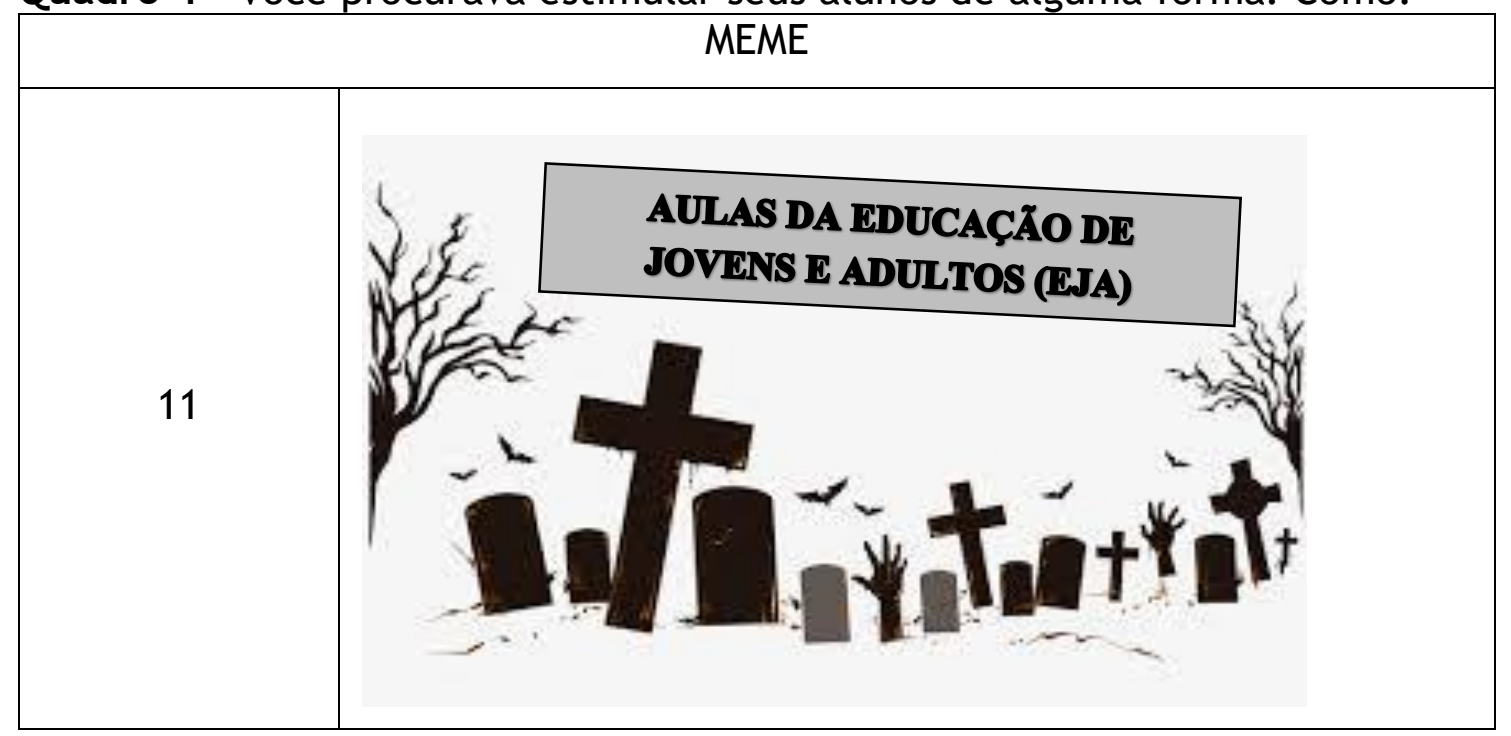

Fonte: Dados da entrevista (2018).

Assim, o meme 11 remete, de forma irônica, ao fato supracitado, pois faz alusão às "Aulas da Educação de Jovens e Adultos (EJA)" em um cemitério. 


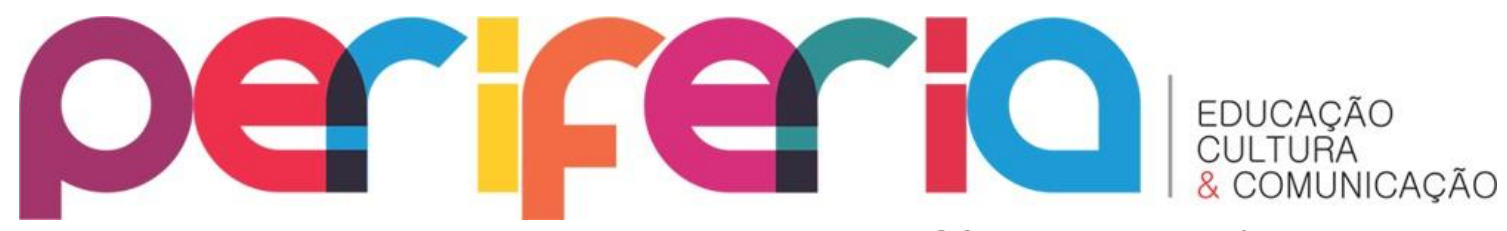

ISSN:1984-9540

DOI: $10.12957 /$ periferia.2019.36856

Reconfigurando aos alunos que foram cadastrados para as aulas da EJA, mesmo já havendo falecido.

A utilização dos memes permitiu formular leituras significativas, sendo que estas informações nos remetem ainda a novas interpretações; e diagnosticar o perfil desses alunos e ex-alunos da EJA. Por meio dos memes é possível utilizar esta abordagem como material didático, como forma de contemplar a dinâmica da EJA, além de estimular uma leitura crítica e significativa.

No Quadro 5, meme $12^{2}$ (Mimétricos), este foi criado através do site Gerar memes, à luz dos depoimentos mencionados neste trabalho de forma colaborativa, pois representa o desejo da qualidade educacional para a EJA.

Quadro 5 - Crítica significativa

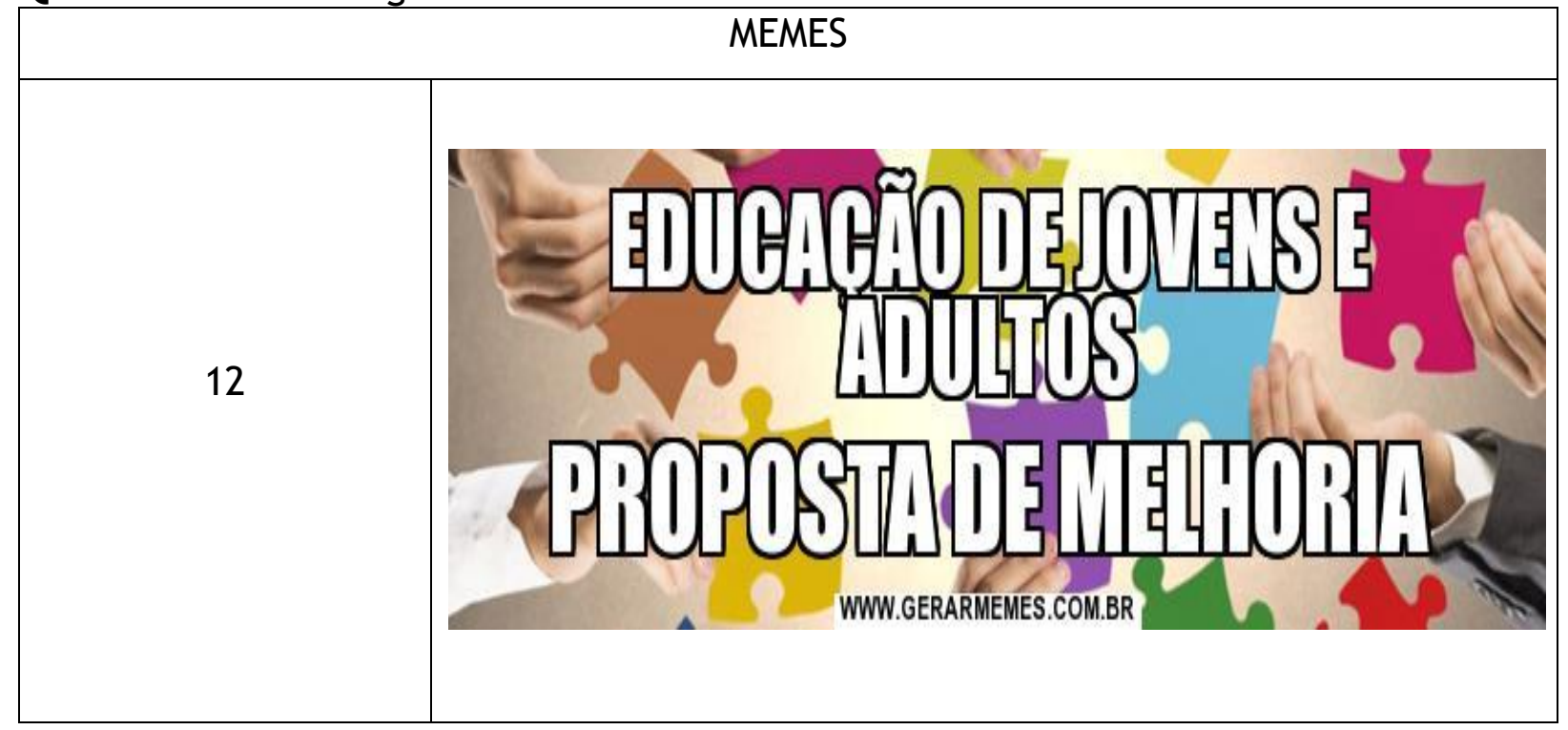

Fonte: www.gerarmemes.com.br (2018).

\footnotetext{
${ }^{2}$ https://gerarmemes.s3.us-east-2.amazonaws.com/memes/725a373c.jpg
} 


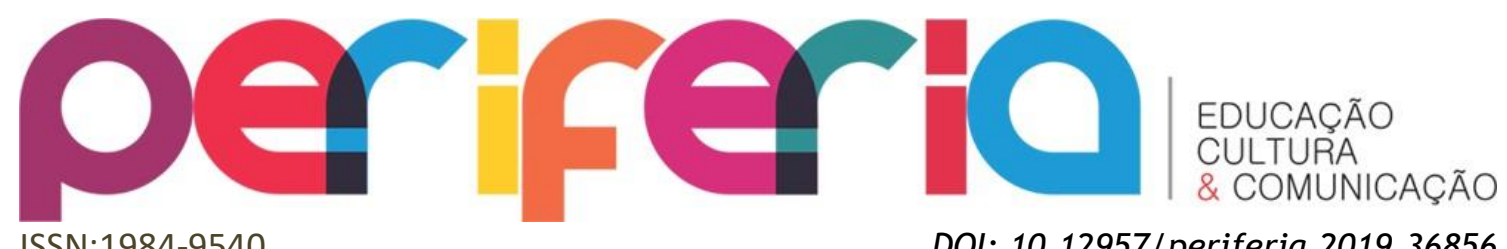

ISSN:1984-9540

DOI: $10.12957 /$ periferia.2019.36856

Desta feita, a proposta de melhoria para a EJA aqui representada está atrelada à ação de repensar as ações educativas para estes alunos que necessitam de uma reconstrução pessoal, física, de modo que o processo seja além da alfabetização e do letramento, mas que contemple a leitura significativa para todas as áreas da vida.

\section{Considerações finais}

Nesta pesquisa, procurou-se apresentar os memes como potencialidades de interpretações das informações no contexto dos alunos e ex-alunos da modalidade Educação de Jovens e Adultos, a partir de dados estabelecidos em entrevistas realizadas pelos discentes do curso de pedagogia da disciplina Educação de Jovens e Adultos. Acrescido a isso, mostrar as concepções dos alunos e ex-alunos da EJA e, assim, com base nas informações, reconfigurar a prática docente e apontar quais os tipos de memes que podem contribuir nas/para ações pedagógicas.

As reflexões de experiências que alcançaram nesta pesquisa se traduzem na necessidade de planejamento no tocante aos materiais didáticos para os alunos da modalidade de Educação de Jovens e Adultos. Assim, um destes recursos didáticos pode-se contar com a presença dos memes na dinâmica dos conteúdos ministrados nas aulas. Justifica-se por ser um instrumento de potencialidades de informações e assim contribuam também nas ações pedagógicas.

Observa-se que estes materiais didáticos podem fomentar coparticipação de criação dos alunos da EJA e/ou com a participação dos graduados do curso de Pedagogia.

Porém, constatamos persistência de problemáticas recorrentes no tocante à modalidade da Educação de Jovens e Adultos que ainda se fazem presentes em função do descaso das políticas públicas. Salienta-se a ausência ou a fragilidade de perspectivas que direcionem ações de fiscalização, práticas contextualizadas com a realidade local, ações educativas de honra para os jovens e adultos. Tal compreensão 


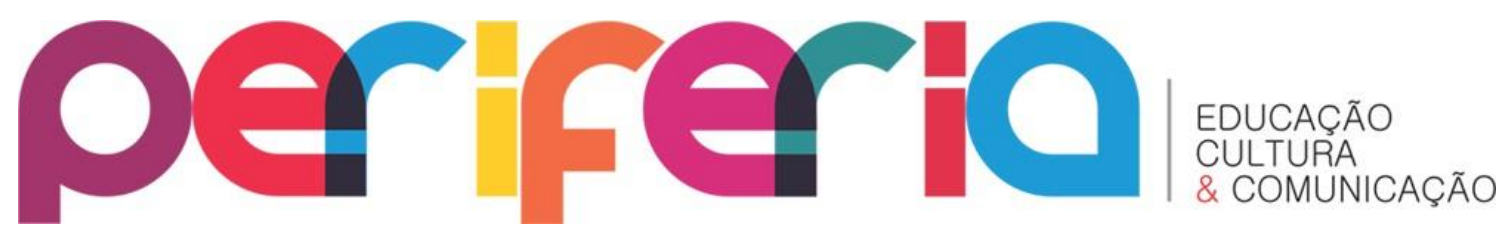

ISSN:1984-9540

DOI: $10.12957 /$ periferia.2019.36856

justifica-se pelos sonhos revelados por estes discentes que estão nas perspectivas de mudanças na vida.

Como sugestão, enfatiza-se que, quando utilizamos os memes no contexto educacional, é possível trabalha-los de forma variada, de modo que a ação pedagógica seja aplicada por meio da colaboração dos grupos (alunos $x$ alunos/ alunos $\mathrm{x}$ professores/ professores $\mathrm{x}$ professores) inseridos no contexto da temática do momento, podendo utilizar memes (replicadores, metamórficos e mimétricos), pois cada um destes estabelece características especificas do planejamento traçado, bem como atenção especial aos memes nocivos, sendo pertinente utilizar memes também em prol do combate. Ademais, é notória a persistência do descaso referente à educação brasileira, mas, contudo, é possível atuar em prol da qualidade educacional de todos os cidadãos.

\section{REFERÊNCIAS}

BRAGA, D. B. Ambientes digitais: reflexões teóricas e práticas. São Paulo: Cortez, 2013.

DAWKINS, Richard. O Gene Egoísta. (1979) Coleção O Homem e a Ciência, volume 7. Belo Horizonte: Itatiaia, 2001.

GOMES, L. F. Redes sociais e escola: o que temos de aprender. In: ARAÚJO, J. C.; LEFFA, V. J. Redes sociais e ensino de línguas: o que temos de aprender? São Paulo: Parábola, 2016, p. 81-92.

JENKINS, H. Cultura da convergência. 2. ed. Tradução de Susana Alexandria. São Paulo: Aleph, 2009.

MACIEL, R. F.; TAKAKI, N. Novos letramentos pelos memes: muito além do ensino de línguas. In: JESUS, D. M.; MACIEL, R. F. Olhares sobre tecnologias digitais:

linguagens, ensino, formação e prática docente. Campinas: Pontes, 2015, p. 53-81.

MARTINO, L.M. Michael Heim: a filosofia do mundo virtual conectado. In: MARTINO, L. M. Teoria das mídias digitais: linguagens, ambientes, redes. Petrópolis: Vozes, 2014, p. 40-43. 


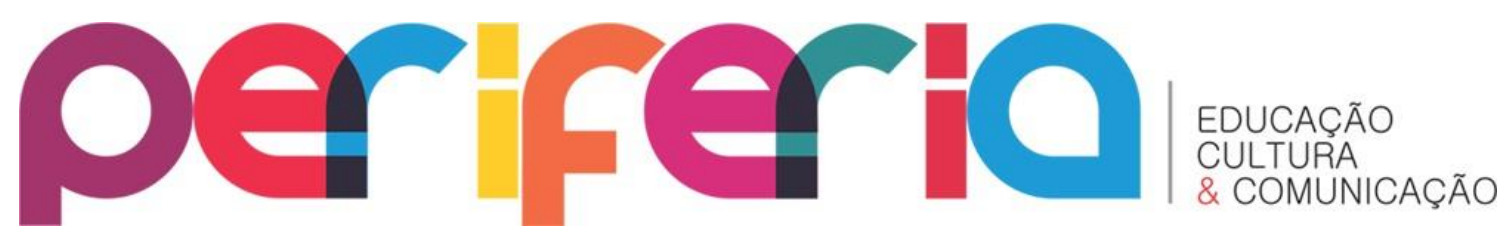

ISSN:1984-9540

DOI: $10.12957 /$ periferia.2019.36856

MENEZES DE SOUZA, L. M. T. O professor de inglês e os letramentos no século XXI: métodos ou ética? In: JORDÃO, Clarissa; MARTINEZ, Juliana Z; HALU, Regina Célia. Formação "Desformatada" práticas com professores de língua inglesa, Campinas, SP: Pontes Editores, 2011.

MENEZES DE SOUZA, L. M. T.; MONTE MÓR, W. Letramento Crítico. Entrevista em vídeo, 2010. Disponível em: http://www.youtube.com. /watch?v=BOOrjl5eurw2010 >acesso em: 20 de jun. de 2010.

RICHARDSON, R. J. Pesquisa social: métodos e técnicas. São Paulo: Atlas, 1999.

SANTAELLA, L. Desafios da aprendizagem ubíqua para a educação. In: SANTAELLA, L. Comunicação ubíqua: repercussões na cultura e na educação. São Paulo: Paulus, 2013, p. 285-304.

TAKAKI, Maria Hirok; MONTE MOR, Walkyria. Construções de sentido e letramento digital critico na área de língua/linguagem, 2017.

ZACCHI, V. J. Dimensões críticas no uso de jogos digitais. In: TAKAKI, N.; MONTE MOR, W. Construções de sentido e letramento digital crítico na área de línguas/linguagens. Campinas: Pontes, 2017, p. 221-242.

\section{Links das imagens:}

Imagem 1

https://cdn.pensador.com/img/frase/lu/iz/luiz_saldanha_ler_e_escrever_e_saber_ viver_lg3m9w8.jpg

Imagem 2

http://educacaopublica.cederj.edu.br/revista/wpcontent/uploads/2016/12/2.refl ex\%C3\%B5es-sobre-o-eja.jpg

Imagem 3

https://longadistancia.files.wordpress.com/2016/06/img_6170.jpg

Imagem 4

https://megaarquivo.files.wordpress.com/2014/09/fitness-na-idade avanc3a7ada.jpghttps://abrilexame.files.wordpress.com/2016/09/size_960_16_9_r elogios127.jpg

Imagem 5

http://rafaelagalvao.com.br/wp-content/uploads/2012/04/sono.jpg 


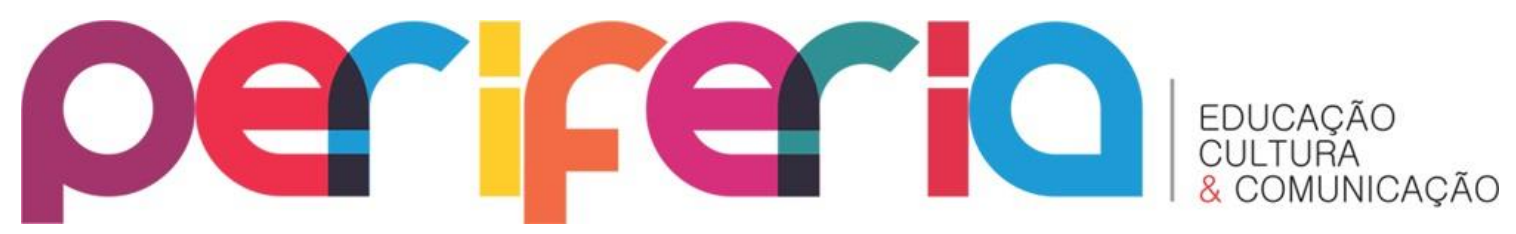

ISSN:1984-9540

DOI: $10.12957 /$ periferia.2019.36856

Imagem 6

https: / / www.wikihow.com/images/thumb/4/46/Give-a-Horse-an-Injection-Step-4Version-2.jpg/aid1754690-v4-728px-Give-a-Horse-an-Injection-Step-4-Version-2.jpg Imagem 7

https://www.zyma.com.br/image/cache/catalog/Quadros\%20Final/Frases/vidamelhor-mockup-500x500.jpg Imagem 8 http://expressodooriente.com/wpcontent/uploads/2013/02/65564_5700906796858 04_1010137067_n.jpg

Imagem 9

http://www.sindipol.com.br/site/images/excluso\%20G.jpg Imagem 10

http://4.bp.blogspot.com/-_Ntsz9Mfnms/VS5qjdGpvRI/AAAAAAABO$\mathrm{Y} / \mathrm{Km} 94 \mathrm{Z} 4 \mathrm{f} 43 \mathrm{nQ} / \mathrm{s} 1600 /$ vergonha.gif Imagem 11 https://png.pngtree.com/element_origin_min_pic/16/07/21/225790db4f70f35.jpg Imagem 12

http://colegioathletics.com/wp-content/uploads/2017/10/proposta.png 